\title{
TRANSLATING DEMOCRACY: \\ CUSTOMARY LAW AND CONSTITUTIONAL RIGHTS IN MEXICO
}

\author{
Eveline Dürr
}

\begin{abstract}
In 1992, Mexico modified its constitution as part of the reformation of its political landscape and recognised cultural diversity. This transition to democracy is embedded in economic and social transformations of the Mexican society and shaped by a revised normative assessment of its indigenous peoples. In the southern state of Oaxaca, the local constitution acknowledged indigenous autonomy in accordance with traditional customs and legal practices (usos y costumbres). I refer to a Zapotec community to discuss the enactment and controversial translation of this new constitutional status. I argue that already existing social and economic divides can be entrenched by the implementation of the new state law. Supporters of usos y costrumbres tend to essentialise 'culture' and 'tradition', whereas opponents appeal to notions of democracy and modernity to advance their claims. Both parties translate the Zapatista inspired international discourse on cultural rights into their arguments, but advocate antagonistic projects. In this article, I conceptualise 'translation' as cultural practice revealing the ambivalent implications of legal pluralism, autonomy, and self-determination.
\end{abstract}

\section{INTRODUCTION $^{1}$}

In the late 1980 s and early 1990s, many Latin American governments acknowledged the multicultural composition of their populations and modified constitutions to recognize customary laws and indigenous legal practices (usos $y$ costumbres). ${ }^{2}$ This rather unexpected recognition of social realities prepared the ground for the acceptance of legal pluralism and consequently for the reformulation of Latin American nations' identities. This process is embedded in profound changes on economic, political and social levels inextricably linked to global frameworks and market economies. The implementation 
and enactment of customary rights in local communities turns out to be a controversial procedure. Because these rights are being constructed as part of national and international discourses, they do not easily translate to indigenous communities, but challenge traditional hierarchies, authorities, and gender constructions.

In this article, I focus on the southern Mexican state of Oaxaca to discuss the nature of these changes and their impact on the everyday life in a Zapotec community by analysing two interrelated translation processes situated on different levels. I elucidate the social implications of translating indigenous customs and customary law into national law. I also scrutinise the translation and reception of global discourses on democracy, participation, self-determination, human rights, progress and modernity into indigenous cultural contexts. Both translation processes are linked to definitions of 'culture' and 'tradition' that form the basis of customary law and constitute contested categories legitimising political power and authority. Furthermore, these translations can be interpreted as cross-cultural encounters, which impact on present cultural politics. In order to gain a deeper understanding of these processes, I will contextualise my findings in the historical, political and social frame of the wider Mexican society and its transnational relationships.

\section{FRAMING THE TRANSLATION OF DEMOCRACY}

The relationship between the Mexican state and the indigenous populations was always imbalanced. As elsewhere in Latin America, it was shaped by exclusion from most social and economic benefits or political participation. During the colonial period, the dominant ideology of the 'natural inferiority' of the Indians legitimated legal inequality, political subordination and economic exploitation of the indigenous communities (Yrigoyen Fajardo 2004:32). In the 19th century, the ideals of a modern, liberal nation revised the relations between the state and indigenous peoples.

Following independence from Spain in 1821 and the subsequent formation of the Mexican Republic in 1825, Mexico was transformed from a colonial feudal system into a modern state. In this process, legal differences grounded in birthrights, class divisions or ethnic affiliations were eliminated in principle and indigenous peoples were de jure granted the same rights as any other citizen. However, this system ignored ethnic diversity and discriminated against indigenous practices and forms of conflict resolution. Mexican governments imposed a normative system of citizenship and property originating in Western philosophies, as they aspired to an integrated, homogenous nation. Com- 
munal land use and customary tenure lost their recognition in the late 19th century, which facilitated the formation of vast estates that deprived smallscale farmers of their vital economic resource (Kuppe 2001:61).

The subsequent exploitation and despoiling of indigenous groups generated enormous tensions and social conflicts, which eventually culminated in the Mexican Revolution in 1910. Even though the modified constitution of 1917 implemented an agrarian reform through the expropriation of large holdings, indigenous common property rights were not legally re-acknowledged until the amendments to the agrarian code of 1940. Land tenure titles seldom received proper legitimated approval, leaving behind vaguely delineated borders and unclear access to other vital resources, like water. Land and water are therefore contested amongst adjacent villages and even family members to this day.

In the first half of the 2oth century, the government aimed to assimilate and culturally integrate indigenous communities into the Mexican nation by fostering education, health services and economic development. In order to manage indigenous affairs professionally, the state founded institutions like the National Institute of Anthropology and History in 1938 (Instituto Nacional de Antropología e Historia) and the National Indigenous Institute in 1948 (Instituto Nacional Indigenista). In the 1970 and 1980s, bilingual education was especially valued and new centres were dedicated to meet this goal. However, the legal framework remained unchanged, and no group's specific rights were articulated by the Mexican jurisdiction. Since the 1960s, this status has been challenged by indigenous groups, peasant movements and by the liberation theology of the Catholic Church, which promoted indigenous rights and reform activities in many Latin American countries in the aftermath of the Second Vatican Council in 1962. In Mexico, political opposition to the dominant party PRI (Partido Revolucionario Institucional), arose in the 1970s and 1980s focusing on issues related to land rights and access to natural resources (Gabbert 1999:17).

Since the 1980s, Mexico has reformed its state and society along neo-liberal lines. In 1982, the Mexican government announced insolvency to the International Monetary Fund (IMF). The slump in oil price reduced the projected foreign exchange earnings dramatically, while interest rates augmented on an international level. This resulted in a deep economic depression and a social crisis. Under IMF tutelage, Mexico's state economy has been transformed towards a neo-liberal model to facilitate investments of multinational corporations. The principals of the social welfare state have been left behind. Powerful 
institutions, including the World Bank and the Inter-American Development Bank, but also non-governmental organisations like Amnesty International and Greenpeace, demanded respect of cultural diversity and pressured the government to embrace a more liberal economy. As a first result, the Mexican Government ratified the ILo Convention 169 and approved it as law in 1989. ${ }^{3}$

Under the presidency of Salinas de Gortari (1988-1994), the neo-liberal state model was consolidated. In order to liberalise the market and to open the frontiers for foreign investors, state enterprises were privatised and the state retreated as a regulator of economic processes (Dehouve 2000:182). These procedures entailed the decentralisation of fiscal and administrative bodies, ultimately strengthening regional claims for autonomy and pluri-cultural recognition. ${ }^{4}$ The neo- liberal shift culminated in the North American Free Trade Agreement (NAFTA) with the US and Canada, signed by Mexico in 1994. This was accompanied by the US's request for democratic trading partners (Clarke 2000: 218).

At the international level, a revised discourse on indigenous communities also contributed to democratisation of the whole of Latin America (Van Cott 2000:208). In 1992, a critical re-interpretation of the 500th anniversary of the European and American Indian encounter coincided with the award of the prestigious Nobel Peace Prize to Rigoberta Mench'u Tum from Guatemala, who identifies as K'iche' Maya. This symbolic act drew international attention to human rights violations occurring in many Latin American countries. At the same time, indigenous peoples gained a higher profile in the public media inducing national governments to become more participatory and tolerant. Many Latin American nations responded to the altered economic, social and political conditions by modifying their legal bonds with indigenous populations. It is in this global-local nexus that indigenous peoples in Mexico have struggled.

TRANSLATING THE ZAPATISTAS: DEMOCRACY, LIBERTY AND JUSTICE

In 1994, when the North American Free Trade Agreement took effect, the Zapatista Army of National Liberation (Ejército Zapatista de Liberación Nacional) emerged in the south eastern Mexican state of Chiapas. In its document 'the Declaration of War and Revolutionary Laws' and subsequent communiqués, the EZLN articulated their demands for democracy, freedom, justice, peace and access to land, education and medical assistance. At a later stage the Zapatistas formulated a critique of neoliberal state models and claimed autonomy for indigenous communities (Mattiace 2003:87). In spite of the popularity of 
this movement, the Mexican government reacted harshly with military operations and aerial bombardment. These actions caused instant national and international protests, which accused the government of human rights violations and pressured state representatives to negotiate with the Zapatista leaders. Moreover, political opposition parties began to adopt a new discourse on indigenous affairs and new intellectual movements supporting indigenous identities came into existence.

Since the Cold War, no other movement matches the EZLN's enormous international prominence (Olesen 2005:2). However, it is important to differentiate between the translation of this movement by external actors like the emerging transnational Zapatista solidarity networks and the lived experiences in autonomous Zapatista communities in Chiapas. Conducive to the international attention of the movement is the ideology of the EZLN, which conveys a vision of a better world on a larger scale in a very general and diffuse way. It aims to create a democracy from below, reaching far beyond the Mexican borders and offering 'an alternative to industrial stratification and the urban order' (Earle/Simonelli 2005:20). Along with these messages go widespread stereotypes of Latin America, ranging from colonial subordination, through romantised guerrillas, to sparkling love of life and unlimited passion. These images allow for myriad projections, identifications and political alignments, especially for socio-critical and left wing sympathisers.

The most prominent figure of the EZLN is the charismatic spokesperson subcomandante Marcos, a mestizo educated in Mexico City, who acts as cultural and political mediator between the national society, the government officials and the indigenous worlds. ${ }^{5}$ With his typical appearance, smoking a pipe with a black mask covering his face, he became the symbol for all faceless and voiceless people, who conceive of themselves as marginalized and discriminated against. Marcos distinguishes himself from other political or religious leaders by his literary capacities and ability to embed his non-dogmatic but still revolutionary messages in sophisticated poetic texts and rich metaphors. By doing so, he allows room for equivocal meanings and manifold interpretations (Huffschmid 2000:166). In this vein, Marcos' messages were translated in multiple contexts, which are not at all tied to Mexican Indian affairs, but still overlap with other political aspirations. He became part of peace initiatives in Afghanistan and addressed issues of colonialism in Africa and Oceania. He is also seen as an active supporter of gay and lesbian struggles for civil rights in countries all over the world. ${ }^{6}$ 
One key reason for the translation of the Zapatistas into numerous international contexts is their strong presence in the Internet, which has been used as a global stage for interactive online dialogues from the very beginning of the uprising (Collier 1999: 171; Olesen 2005:181). The unusual combination of a rather simple indigenous army, but with sophisticated, voluminous messages and modern information technology contributed to the fascination of this movement. The messages of subcomandante Marcos and the various communiqués of the EZLN were subsequently translated into many languages and distributed through news networks. The Zapatista online mobilisation of an international audience illustrates the significant impact of 'cyber policy' on national policy (Huffschmid 2000:141) and helped to reactivate already existing networks of solidarity and social critique. However, it is important to note that the majority of Zapatista internet messages do not come from the Mexican Zapatistas themselves but from US American organisations, like the ; Ya Basta! and Acción Zapatista, based in Austin, Texas. Shortly after the rebellion, this group acquired with the permission of the Zapatistas the domain www.ezln. org. This site serves as a multi-lingual information pool on all affairs related to the Zapatistas, including quotations of subcomandate Marcos, answers to FAQ, the Zapatista anthem, and the latest results of negotiations with the government. Multiple discussion forums provide possibilities to actively participate in Zapatista inspired dialogues and to establish transnational bonds by attending conferences the EZLN have initiated all over the world. ${ }^{7}$ In this virtual space, translation evolves into a medium of performance, representation and cross-cultural encounter.

The Internet itself is seen as a symbol of democracy, despite this being a rather uncritical view given the digital divide of the world's population, which particularly excludes marginalized individuals and groups. However, the virtual space offers new room for self- representation and the potential to transform indigenous peoples from passive victims of colonialism to active political players. This new self- representation and self- perception reflects back into the discourse of the dominant Mexican society and into the indigenous communities. To facilitate communication, the messages were translated into four indigenous languages beside Spanish (Tojolabal, Tzeltal, Tzotzil and Chol) as well as from indigenous languages, for example Tojolabal, to Spanish to English (Mingnolo and Schiwy 2003: 8, 12). Besides language, subcomandante Marcos explicitly emphasises the translation of indigenous cosmologies and concepts in the political organisation of the EZLN as a form of 're-education' or 're-modelling' (Marcos 1997:148f., 338-39). However, as illustrated below, the notifications of political awareness and cultural rights have ambivalent effects on the everyday life in the local communities. 
Increased military presence, political violence and human rights abuses are all signs of the growing challenge of the indigenous mobilisation to the Mexican state. In Chiapas, self-declared autonomous governments, sympathetic to the EZLN, are subject to harassment and intimidation (Collier 1999:166, Stephen 2003: 193). Polarised internal fragmentation accompanied by violent episodes, are also observed in many communities in the aftermath of the rebellion. For example, San Pedro Chenalhó, a Tzotzil community in the highland of Chiapas, is split into pro- and anti-Zapatista fractions and further sub-divisions. Similar processes occurred in San Andrés Larraínzar, where autonomous and PRI governments existed simultaneously. In those cases, the declaration of autonomy led to both conflicting intra-community claims and to increased paramilitary activities (Stephen 2003:198). Other examples of severe intracommunal conflicts between pro government and independent groups, along with economic polarisation and religious fragmentation are reported from $\mathrm{Zi}$ nacantán and Chamula (Rus and Collier 2003:33-61). While Zinacantán was able to mitigate the division after 1994 by reforming the municipal powers and incorporating Zapatista discourses to some extent, Chamula did not succeed in reconciling the conflicting religious and political interest groups. Many of the individuals who were forcibly expelled were not religious converts in the first place but belonged to the political opposition challenging the ruling elite (Speed and Collier 2000: 902). In contrast, in Tojolobal communities, the mere existence of distinct religious groups did not provoke conflict, even though not all Tojolabal communities follow the same political orientation (Mattiace 2003:147).

\section{TRANSLATING CUSTOMARY LAW INTO CONSTITUTIONAL RIGHTS}

In 1992 and with further amendments in 2001, Mexico revised its constitution and acknowledged the nation's multicultural composition officially. The constitution considered self-determination and local customary practices in the national legal framework. ${ }^{8}$ However, this constitutional acknowledgement is based on problematic equations. It is presumed that customary law and constitutional law are similar in nature and therefore can be treated and implemented equally, regardless of the national or indigenous context. This ignores the fact that there are crucial normative and procedural differences between the textures of the two legal systems. In contrast to the national system, indigenous practices are less segmented and lack separation between administration of justice and forms of social control. Kuppe (2001:63) points out that customary law is a non codified, unwritten set of norms creating the frame for regulating and defining rights, duties and forms of punishment within a specific cultural realm. It is not enshrined in fixed terms but linked to the 
social structure and worldview of the group and individuals involved. It is primarily based on reciprocity, compromise, consent and discourse. The individuals' relationships with each other and the perceived benefits for the whole community are considered. Conflict resolution includes the participation of all parties involved and is negotiated rather than managed according to an abstract set of rules. Hence, it is more flexible than a general instrument of legal control and can be attuned to the specific cultural patterns of the group (Kuppe 2001:63).

Van Cott (2000:214, 228) observes that customary law and national law do not pursue the same principles. National law seeks punishment of the guilty, while customary law aims at reconciliation and consensus and gives prominence to dialogue, rather than punishment. National law considers the individual whereas customary practices tend to include the kin groups of the offender. The appropriate degree of punishment is subject to negotiation and depends heavily on status, age and gender of the litigant and his or her family's relationship with the community. The forms of sanctions differ as well. Exclusion from the community, forced labour or physical punishment are far more frequent than imprisoning.

However, it is important to note that customary law is neither an ancient law nor a pre-Columbian set of rules, but the political product of power relations between the state and indigenous communities (Gabbert 2005:311, 312). By relating customary law to the 'traditional' culture of indigenous groups, it is implied that it refers to an ancient, unchanged concept, which ignores the adaptive and flexible nature of social organisations. As such it is constantly re-negotiated and modified according to the groups' relationship with the dominant society. ${ }^{9}$ Local political leadership and key positions are also contested and internally shifting power structures impact strongly on the juridical system. In contrast to national law, a codification of customary law implies a profound transformation of its nature and specific characteristics.

A further translation problem occurs when it comes to re-translating and enacting the new constitutional status into the indigenous communities. This is related to a fundamental misunderstanding of the concepts 'nation' and 'culture' such that culture is translated as nation and both are portrayed as homogenous. Gabbert (2003:130, 2004:9) observes that even leading scholars in the current theoretical debate on multiculturalism tend to use 'culture' interchangeable with 'nation' or 'people', as entities of persons pursuing a collective end. ${ }^{10}$ However, anthropological research has extensively demonstrated that culture is by no means a homogenous category but rather a contested and 
constructed concept, shaped by the agency of individuals and interest groups in relation to specific contexts and perceived benefits (see e.g. Baumann 1996, 1999, Werbner and Modood 1997).

Given the diverse array of Mexican indigenous groups the assumption of a shared cultural pattern at a wider regional level is misleading. Fundamental normative and hence legal differences and customary practices exist between the various communities, even if they share the same territory or belong to the same language group. Differences include important issues such as belief systems or title to inheritance to vital economic resources, especially arable land (Mattiace 1997: 62; Gabbert 2004:4,5). This leads to two further crucial questions: what constitutes indigeneity and who defines indigenous 'culture'?

Unlike in the US, where American Indian tribes decide on their members themselves, in Mexico it is the state that assesses and defines the category indigenous. ${ }^{11}$ The state institution CONADEPI ${ }^{12}$ determines the identification of people as indigenous based on the single criterion of language. According to the census, 56 language groups are officially differentiated. These language groups are comprised of individuals who are older than five years of age and speak an Indian language. However, language groups are often wrongly translated as ethnic groups. Those sharing language may not share a common cultural identity, and may differ enormously in number and geographical distribution. Their economic activities range from farming in peasant communities to market economies with regional or craft specialisation, division of labour between different villages in one region and links to the international tourist industry (Beals 1975, Cook and Diskin 1976, Dürr 1996: 64-125, Clarke 2000: 101-117, Cohen 2004:15).

Based on official classification, $7 \%$ of the 97 million Mexican citizens are considered to be indigenous. ${ }^{13}$ This is more a tentative orientation than an exact number, as the national definition of indigenous does not necessarily correspond with the self-evaluation of individuals or groups or its acceptance by others. Individuals who do not speak an Indian language might perceive themselves as indigenous or call themselves Indian, and others who speak an Indian language, might perceive themselves as non-Indians. For example, in the Central Valley of Oaxaca, Zapotec speakers do not conceive themselves to be Indians in order to be differentiated from highland groups, especially Mixe, who are negatively associated with stereotypes (Cook and Joo 1995:37). Similar inequalities and classifications shape the relationship between Mixtecs and Triqui (Clarke 2000:165, 177). Because of the fact that many individuals are bilingual (Spanish and an Indian language), they can apply the identity that 
favours their status in a specific situation or social context. Thus, cultural identity is constructed through language, but in regard to the local dialect and to the community to which the individual belongs.

Other important identity-creating elements, like religious organisations for celebrating and sponsoring fiestas or traditional costumes, which serve as visible markers, must also be interpreted in context (Dennis 1987:19). Campbell (1994:53-4) notes that in Juchitán located in the costal area of Oaxaca, only people who had been born and had their placenta buried there could qualify as Juchitecos and be eligible for a political career. Juchitecos perceive themselves as people with a distinct language, a specific set of customs, kinship systems, gender constructions and customary laws. Ethnographic studies showed that inter-community relations, even amongst neighbouring villages of the same language group, are often unfriendly, if not hostile (De la Fuente 1965:31, Dennis 1987:16, Greenberg 1989:132f, 147). However, in recent years, indigenous movements, migration and transnational relationships have strengthened ethnic identities beyond the confines of the village level. ${ }^{14}$

In summary, the recognition of customary law in Latin America is part of a broader political project based on democratisation, participation and self-determination (Kuppe 2001:63, Van Cott 2000:211). It is embedded in the global market economy and meets the needs of foreign investors who demand minimal democratic standards and stable political conditions. The increasing number of individuals classified as indigenous reflects the new political dimension, power and status attached to this group in the wider society. Their former categorisation as farmers (campesinos), based on class, has been widely replaced by ethnicity.

The re-definition of the states' relationship with the indigenous population is also strongly shaped by a revised international discourse. Human rights groups, anthropologists and other solidarity networks called arduously for freedom, justice and democracy. However, these concepts originate in Western philosophy and history rather than in indigenous life worlds. Indigenous hierarchies, generation gaps and gender differences were not always taken into consideration when these claims were made. If indigenous people are allowed the autonomy to develop their own definitions of human rights according to their cultural context, then such rights would no longer be considered as an imposition of Western values nor would they be so easily misused by government officials as pretexts to interfere in indigenous affairs whenever they deem it appropriate (Speed and Collier 2000: 878). Nonetheless, indigenous groups actively appropriate these globalised discourses and translate 
them into their own contexts (Speed and Collier 2000, Speed 2002).

The human rights discourse, even though relatively recent, has become a major force in negotiation processes between indigenous movements and government officials. In Chiapas, the EZLN and many Zapatista based communities have deployed this rhetoric in relation to cultural rights as they mobilise a solidarity network in their struggle for autonomy and resistance against Mexican government repression. By utilising this discourse to achieve their own goals, local communities reshape and re-enact their identity as 'indigenous' (Speed 2002). But the translation of human rights by indigenous activists in their own community can also be strategically used to reinforce and reproduce social inequalities, competing interests and economic fragmentation - rather than levelling them. At times, indigenous leaders may of course violate human rights by claiming the right to exercise 'traditional' cultural practices, which suit their aspirations.

TRANSLATING CONSTITUTIONAL RIGHTS INTO CULTURAL REALITIES IN OAXACA

At the individual state level, further constitutional amendments were introduced and new laws adopted. In Oaxaca, the government revised its electoral legislation and incorporated detailed articles into the state constitution. In 1995, with further alterations in 1997 and 1998, the state guaranteed indigenous autonomy to some extent and allowed the right to impart justice in accordance with local customs (usos y costumbres). This validated the jurisdiction of traditional authorities and organs of dispute management. Furthermore, regulations for implementing this new legal status were passed and sanctions were legislated for in case of non-compliance. In contrast to Chiapas, where the government tries to prevent indigenous autonomy, the Oaxacan state's constitution explicitly not only tolerates but also protects and legitimises plural legal frameworks and the regulatory juridical powers of indigenous authorities. ${ }^{15}$ This is related to divergent historical experiences and present conditions in Oaxaca und Chiapas.

Oaxacan communities, based on small-scale subsistence farming, managed to retain significant control over communal land during the colonial period and beyond, while mestizo-owned coffee plantations and cattle ranches dominated Chiapas. As a result, Oaxacan municipalities have governed themselves, although not in a much less corrupt way. Hostilities and land conflicts typically erupted among indigenous neighbours, whereas in Chiapas state repression and economic exploitation created a common enemy. Multi-ethnic allianc- 
es and regional cooperation across ethnic groups evolved in Oaxaca to a far lesser degree than in Chiapas, where they were stimulated also by the progressive Catholic Church and leftist external actors since 1970 (Stephen 2002: 219; Mattiace 2003: 109).

Within a similar territory, Oaxaca's indigenous population outnumbers Chiapas by almost $50 \%$ and cultural, social and administrative fragmentation is enormous. Nearly half of the population is classified as indigenous and categorised into sixteen linguistic groups. Different dialects exist within some of the major languages, such as Zapotec and Mixtec, which are not understandable to each other, even if spoken in adjacent villages (Clarke 2000:161). A common basic structure is provided by the municipio, the principal unit of local government below the level of the state. These administration entities represent an important spatial and political framework, within which social bonds are renewed for example by marriages, and economic resources, especially land and water, are managed. Oaxaca's 570 municipios with an average of 6,00o persons per unit are much smaller than elsewhere in Mexico and five times the number of municipalities as in Chiapas. ${ }^{16}$

The Oaxacan recognition policy is certainly influenced by the Zapatista uprising in the neighbouring state of Chiapas and the subsequent political mobilisation of the indigenous communities, but the specific political conditions in Oaxaca are also important. In the aftermath of the uprising political elites in Oaxaca introduced preventive reforms and negotiated with the leaders of indigenous movements, probably also to keep them loyal to the state government and prevent them from allying with the opposition (Trejo 2001:25, 29). Velásquez (2000: 135) suggests that the ruling PRI assumed that their traditionally strong ties with most municipios would not be affected seriously by usos $y$ costumbres. Anaya (2004: 416), by referring to Charles Taylor's 'politics of recognition', concludes that the main factors comprise a crisis of legitimacy and threats to governability of the PRI, along with indigenous strategic alliances with crucial political actors.

In order to understand the impact of the new legislation on the local level, it is necessary to clarify the basic structure of the municipal government (ayuntamiento constitucional), which exercises control over both political leadership and communal resources. It consists of a specific system of posts (cargos) divided into executive, legislative and judicial levels. The cargo- system involves the hierarchy of offices of the municipal government on the civil side, paralleled in religious organisation by the cofradías or mayordomías honouring Catholic saints, especially the patron saint of the village. Hence, the secular 
system often overlaps with the Catholic fiesta system (Clarke 2000:185, 186, 192). A presidente municipal is head of the executive power with his alternate (suplente), the legislative level comprises councilmen (regidores) and alternates, and the judicial branch is headed by a so-called alcalde and his suplentes. The numbers of the posts vary from municipio to municipio. District offices, state and federal governments consider the president as the embodiment of the community and hold him responsible for all municipio related matters (Clarke 2000:195). The municipio members perceive the presidente as political middleman, key representative and intermediary with the federal government, especially in the case of land disputes with neighbouring municipios. An essential part of municipio life is tequio, communal labour projects without compensation carried out by adult males over the age of 18 . This obligatory work involves construction and maintenance of roads and bridges, schools and health clinics and other activities deemed to be of public benefit. These works are supervised by the ayuntamiento constitucional.

The uncompensated and hierarchically structured indigenous government positions are nominally filled on the basis of election by communal assembly or by consensus for a three-year term. Young men start with the lowest cargo and work their way up to be eligible for higher positions. The elders of the community form the council of ancianos consisting of men who have already held leadership roles and served in different positions (Clarke 2000: 193, 194). The members are ranked according to seniority and cultural capital expressed in terms of language abilities, knowledge of tradition, experience in conducting religious festivities and time elapsed since holding the most prestigious post. They represent both as individuals and as a collective body the highest authority and moral institution of the community and advise the president. ${ }^{17}$ These political posts have been closed to women in the past. However, this situation changed considerably and women are claiming or are already exercising political power in several municipios. ${ }^{18}$

It is important to note that the municipios are not isolated entities, but integral parts of the wider national community. Political parties and state laws have always affected the elections of the ayuntamientos municipales. Prior to 1995, the elected candidates were usually affiliated with the PRI, which ruled Mexico for 71 years from $1929-2000 .{ }^{19}$ Since the 1980 s, the opening of the political system allowed new parties to emerge which are now competing for votes in the $m u$ nicipios in order to strengthen their political position on the state level.

In the 1990s, several state-aided programmes were launched to support specific sectors in marginalised municipios. The funds were redistributed by the 
authorities of the municipios and invested in public buildings, infrastructure, water, electricity as well as in education and scholarships (Dehouve 2000: 183) ${ }^{20}$ The growing importance of the municipio as a self-governing entity is also reflected in the fact that the World Bank has established a Municipal Funds Programme that has targeted Oaxaca's municipalities and encouraged grass-root decision-making processes about priorities given to development projects (Clarke 2000:186, 214). This means that the municipio has evolved into an active player in the wider political landscape on the state's level and represents an important actor in the process of decentralising public administration.

\section{TRANSLATING GLOBAL DISCOURSES INTO LOCAL COMMUNITIES}

The new constitutional law granted the municipios two options to run their political affairs. The authorities can be elected by usos $y$ costumbres, this means according to traditional customs based on the cargo- system, or they can be democratically elected as representatives of a national political party by secret ballot. Currently, 418 out of 570 muicipios in Oaxaca formally voted their authorities by the system based on usos y costumbres. ${ }^{21}$

The practical realisation and implementation of multiple legal systems and democratic votes into indigenous contexts turned out to be a highly complex and controversial procedure. In the first instance, the municipios have to agree on the election mode and to decide which jurisdiction should be mandatory. ${ }^{22}$ This became a major point of contention because the two election modes are fundamentally different in nature and give weight to very different political actors and interests. According to the traditional system, major decisions are carried out by representatives of the municipio based on consensus rather than on a democratic vote, without consultation with all municipio members. This contradicts the structure of the national system seeking a democratic process with the participation of all eligible community members. Because of the internal differentiation and heterogeneity of interests in the municipios, it seems to be almost impossible to find a system attending to the demands of all sides. So far no binding mode of conflict resolution could be developed in case of disagreement to the voting. Consequently, external actors like governmental, federal or non-governmental bodies interfere to resolve the disputes. This means that the final decision is deferred ultimately to state institutions again, which follow their own political principles. However, not all forces in the communities invite external bodies to interfere, because this contradicts their definition of autonomy and self-governance.

In the case of Santo Domingo, ${ }^{23}$ a Zapotec municipio with 3,500 inhabitants, 
located in the costal area of Oaxaca, no decision agreeable to all interest groups could be achieved. This resulted in the division of the municipio into two opposing units establishing distinct and competing ayuntamientos. The struggle over the appropriate jurisdiction was carried out with bitter aggressiveness, including homicide, and led to extreme tensions across kin groups and even family members. Similar episodes have been recorded from other municipios, where the controversy over the election mode could not be settled amicably. In some cases, caciques, often endorsed by governmental political forces, prevented opponents from attending the assemblies to define the electoral procedures. The opponents, in return, do not acknowledge the legitimacy of the election and report the incidence to the State Electoral Institute of Oaxaca, where the electoral result is supposed to be validated. In other cases, local elite forces try to manipulate customary rule to enforce their claims and use it as an excuse to penalise dissidents. Internal fragmentation and animosity are further enforced by the opening of the municipios for various national political parties trying to influence decision-making processes on the local level by applying pressure on the communities to change their system of government (Cohen 2004:14).

Other municipios switch from one election mode to the other and back again in a relatively short period of time because the political majorities are constantly shifting. Violence does not necessarily prevail in these cases, but they demonstrate that the voting rights are contested and majorities are unstable. Violent conflict has occurred when affiliation to non-Catholic churches is used as the basis for excluding people from voting rights. The contention over the election mode polarises further the already existing division between 'traditionalists', usually referred to as Catholics, and the Protestants, widely perceived as 'modernisers'. Many Protestant churches oppose customs and traditions as pagan and repugnant. Increasing religious fragmentation contributes to the modification of the cargo- system and favours the separation of religious and political posts (Collier 1999:57). Protestants are obviously reluctant to take part in mayordomías and celebrations for Catholic saints, but not necessarily in participating in civil cargos or tequio. Gross (2003:489) convincingly points out in his critical analysis of the impact of Protestant churches in the Sierra Juárez that religious conversion can provide an alternative for political dissidents, especially in areas controlled by caciques, local bosses.

In Santo Domingo, a cacique opposed the voting according to the political party regime. Participation in the community assembly was granted only to married men who resided in the community and who already served in the cargo- system. The disenfranchisement of other community members stirred 
protest and no agreement could be achieved between the contending groups. The cacique and his extended family was especially supported by the poorer families of the community, because in return for their services he sponsored the fees for the education of their children and took care of other expenses, like medical assistance. In some cases, he was also the godfather (padrino) of their children and played an important role in the ritual kinship system. Those families felt protected and supported by him and he in return, expected their loyalty. His opponents accused him of abusing his power. The local priest, who refused to baptise the children of the cacique, supported their view. The dispute evolving from the voting system entrenched the division of this community that dates from before the reformation of the legislation. Intriguingly, as in similar cases in Oaxaca and Chiapas, the opposing parties each invoked a similar rhetoric to achieve control over legislation (see Collier 1999:57, Speed and Collier 2000, Speed 2002).

The cacique portrays himself as defender of the traditions enshrined in usos $y$ costumbres and stresses the altered legal status and constitutional guaranteed rights respecting and even actively protecting indigenous traditions and normative systems. The supporters refer to the conservation of their cultural heritage and declare the traditional way of nominating authorities as an essential part of it. The influence of the political parties is addressed as being a threat to indigenous traditions causing corruption and being the main cause of disharmony. In keeping with the rhetoric disseminated by solidarity groups in the spirit of the EZLN, Santo Domingo's cacique contends that authentic indigenous culture should be defended and preserved against intruders and bad influences from the outside.

By arguing in this vein, a specific cultural image is produced and presented. Although the justification is to defend original values and identities by pointing to 'traditional', 'authentic' and 'indigenous', the image produced is formed according to specific interests and perceptions. In this context, the definitions of 'culture' and 'tradition' become powerful strategies to legitimise inequality and to consolidate superiority.

This argument reveals an essentialist and static understanding of culture, along with idealisation of customary law realities. By referring to 'traditional' and 'authentic', it is implied that these practices have been passed down from generation to generation, in a rather unchanged and uncontested way, based on mutual agreement or consensus, downplaying the tensions that already existed before the new legislation took effect. A harmonic picture of a coherent and integrated community is promoted retrospectively which should be pro- 
tected against modern and external influences, corrupting and contaminating the 'authentic' and 'pristine' indigenous culture. Ethnographic evidence shows that practices perceived as 'traditional' are by no means very ancient but invented and implemented as needs arise. Customary practices never existed totally separated from national law, but were always modified in accordance or in opposition to state law and shifting political winds in the wider society and the community itself. ${ }^{24}$

Other supporters of usos y costumbres in Santo Domingo comprise mainly individuals who held offices in the cargo- system and constitute the elite of the village. As in many other communities, the highest level of the administrative hierarchy tends to be occupied by men with economic resources, formal education and contact with the national society. Only such men are able to serve in the cargo- system without compensation (Clarke 2000:201). Even though not all agree with the rule of the cacique and may even challenge his power, they do still reject the vote according to the national system.

It is important to note that in the last decade, socio economic differentiation of the municipios was continually increasing and the more entrenched class divisions tended to enhance social fragmentation. This process originated in government programmes, which were implemented in the 1950's with the aim to foster economic and social development of indigenous communities perceived as obstacles to the modernisation of the nation state. In order to stimulate integration by assimilation, members of indigenous groups were educated as so-called promotores culturales, key persons to bring about cultural change and trigger modernisation. They often played a leadership role in cultural brokerage and in mediation between the dominant society and peasant communities living in remote and marginalized areas. ${ }^{25}$

In spite of their abilities and education however, these individuals did not enjoy the same social possibilities as mestizos or white members of the Mexican society and felt discriminated against. This had the effect of them becoming stakeholders of indigenous affairs and representations (Gabbert 1999:19). As indigenous intellectual leaders during the 1970 s and 1980s, they strongly rejected assimilation and disappearance into national society, as once intended by the government. Instead, they argued in favour of the endurance of ethnic identities and asked for the acknowledgement and respect of ancestral culture in spite of capitalist and modernisation theories popular at that time. The Catholic and Protestant churches in Oaxaca and in Chiapas played important roles in the initial phase of this development as well. Initiated by Protestants and successively mirrored by the Catholic Churches, the Bible was translat- 
ed into indigenous languages and peasant cooperatives came into existence (Trejo 2001: 21, 23). As peasant communities have modernised and the younger generation has become more educated and privileged, demands for ethnic recognition and self-control of economic and social development have grown. Ultimately, the state and the churches promoted the creation of networks, language revival and identity renaissance unintentionally. Powerful indigenous movements emerged out of their efforts, led by a young, indigenous, bilingual elite. This was conducive to the state's recognition of pluri ethnicity and the right of indigenous communities to exercise jurisdictional functions in accordance with their own cultural rules and procedures. In addition, many nongovernmental organisations and indigenous movements deemed these rights as key issues and perceived the consolidation of the cargo- system as a vital element to assuring indigenous autonomy and as a means to minimise the national political parties' influence in the municipios (Clarke 2000:181).

However, not all individuals could advance in the political hierarchy or profit from political participation and improve their social status within the traditional system usos y costumbres. Due to gender, age or a lack of economic resources, many people were not able to take over a post, especially without compensation for additional expenses, such as sponsoring an appropriate celebration for a saint. In contrast, political representatives of national parties are entitled to salaries and the communal, unpaid labour obligations, tequio, become obliterated.

In Santo Domingo, the group of people favouring the political party system refers to similar discourses as the opposing party to legitimate their position, but translate and situate them differently in their argument. They appeal to the principles of democracy, participation, equity, emancipation, modernisation, progress and human rights to critique abusive caciqual power. As human rights groups have strongly advocated, they claim their right of access to political positions regardless of age, economic resources, gender or loyalty to a dominant elite. In their perspective, these rights can only be put into effect by elections according to the national political parties whereas the traditional cargo system constrains the development and advancement of the community and facilitates repression. Modernisation and self-determination are key words in their discussions. Quotations of the EZLN's articulation of indigenous women's rights contribute to their profile of progress and emancipation.

While the supporters of usos y costumbres point to the new law to conserve and protect the 'traditional culture' in order to preserve their power, the opposing party insists on the application of human rights to stimulate change, to 
achieve social mobility and to allow democratic political participation. Each side claims to occupy the moral high ground and considers itself superior either for its determined traditionalism or its belief in progress and modernity. Both parties translate facets of globalised discourses on democracy into their representations and performances. Finally, the case was referred to the authorities in Oaxaca in order to mediate between the conflicting sides. ${ }^{26}$ This means that failure to reach internal agreement allowed state-controlled forces to interfere again in Santo Domingo's political affairs.

\section{CONCLUSIONS}

Increasing communication across languages and cultures in the now global and interconnected world creates dialogues and enables individuals to actively participate in articulating and translating cultural identities, concepts and cosmologies. In Latin America, this contributes to the crossing of ethnic boundaries and the formation of transnational movements aiming towards democratic and multi-cultural nations, but also to the creation of new barriers, contentions and antagonisms. Specific mediators, often located in the margins of society, appropriate and re-define features of culture and 'Indianess', tradition and modernity to reassert or challenge hierarchies and legal frameworks. Translating and mediating are never neutral acts but involve always intentionality and ideology (Rubel and Rosman 2000:13, 18).

The recognition of diversity on a national and international level is certainly important, but the consequences of the re-definition of the state as pluri-cultural or multiethnic are controversial at the local level. In contrast to the assumption of many international solidarity groups, political activists and social movements, the enactment and translation of democracy, participation and self-determination into indigenous contexts carries a huge potential for conflict. The dissemination and translation of political vocabulary, which originates in specific social realities and historical developments, can result in entrenching polyphony, power relations and interests in indigenous everyday life. In order to stabilise the democratic project and put into effect the constitution's goal of strengthening, integrating and empowering indigenous communities, cultural conditions, constraints and potentials need to be considered. The meaning of cultural or, rather, human rights and the intentions of their application in a specific social situation are crucial criteria to assess whether they contribute to social justice (Speed and Collier 2000: 879). This becomes especially obvious when competing parties share common discursive frameworks but pursue contradictory projects, as is the case in Oaxacan and Chiapan municipalities. This refers to ethnographic analysis of cultural or 
linguistic translation, which is never confined to single ideas or words, but always stipulates contextualisation and knowledge of broader cultural concepts and underlying structures.

\section{NOTES}

1 This article is based on ethnographic fieldwork conducted in 2001 and 2003. The final version has benefited from critical comments of an anonymous reviewer. I also would like to thank Gordon Winder for his helpful suggestions.

2 Examples are Guatemala (1985), Nicaragua (1986), Brazil (1988) Colombia (1991), Paraguay (1992), Peru (1993), Bolivia (1994), Argentina (1994), Ecuador (1983 and 1998), Venezuela (1999), see Gabbert (2004:2, 13) and Yrigoyen Fajardo (2004:33).

3 Convention 169 concerning Indigenous and Tribal Peoples in Independent Countries, adopted by the International Labor Organisation (ILO) in 1989, see especially articles 8.1-3 and 9.1-2. Article 9.1. states 'To the extent compatible with the national legal system and internationally recognised human rights, the methods customarily practised by the peoples concerned for dealing with offences committed by their members shall be respected. Full document is available from the office of the UN High Commissioner for Human Rights at http:// www.unhchr.ch/html/menu3/b/62.htm.

4 Hale (2002) questions the assumption that multiculturalism challenges neo-liberal political-economic practices. Based on ethnographic data from Guatemala, he suggests that it rather divides acceptable and radical demands for cultural rights.

5 The term mestizo refers to offspring of white and indigenous in colonial and independence years. Since the 1920's, it has become a cultural category describing hispanised Mexicans. This is related to the imagined construction of the 'nation of bronze' as identity frame for the Mexican nation (Clarke 2000: 162). The term ladino, common in Chiapas and Guatemala, is absent in Oaxaca.

6 This is reflected in the following lines, which are cited on numerous websites, e.g. http://www.black-rose.com/articles-liz/actupwto.html: 'Yes, Marcos is gay in San Francisco, Black in South Africa, an Asian in Europe, a Chicano in San Ysidro, an anarchist in Spain, a Palestinian in Israel, a Mayan Indian in the streets of San Cristobal, a Jew in Germany, a Gypsy in Poland, a Mohawk in Quebec, a pacifist in Bosnia, (...) He is every minority who is now beginning to speak and 
every majority that must shut up and listen. (...) - this is Marcos.' Refer also to his book Marcos, Subcomandante (2002) Our World is Our Weapon. Selected Writings of Subcomandante Marcos. Edited by Juana Ponce de Leon. New York: Seven Stories Press.

7 Apart from textual and visual messages transmitted by the websites, music provides a more emotionally translation of Zapatista messages. Many bands in Mexico and worldwide refer to the Zapatista and an imagined pan-Latin American solidarity in their songs.

8 'The nation has a pluri-cultural composition (...) This constitution recognises and guarantees the right of the indigenous peoples and communities to free determination and, consequently, autonomy to: (...) Applying their own normative systems in the regulation and solution of internal conflicts, subject to the general principles of this constitution (...) electing in accordance with their norms, procedures and traditional practices their authorities and representatives to exercise their own form of internal government (...) preserve and enrich their languages, knowledge and all aspects which constitute their cultural identity (...). Refer to: Constitución Política de los Estados Unidos Méxicanos, Article 2, see http://info4.juridicas.unam.mx/ijure/fed/9/, translated by E.D., see also Gabbert (2004:3).

9 See the classical comparative study of two different Zapotec villages and their diverse legal systems in regard to their social structure and relationship with the dominant society, provided by Laura Nader (1964), see also Nader $(1989,1990)$.

10 Gabbert (2003:130, 2004:9) refers to Will Kymlicka (1995:18) and Charles Taylor (1993:20) who use the term culture and nation interchangeably. He states that by doing so, they apply an old model of the nation-state to the new legal entity of indigenous peoples.

11 It is important to note that there is no common definition of the category 'indigenous' in Latin America. In general, approximately 10 per cent of the Latin American population is classified as indigenous. However, the range in different countries is enormous, with less than one per cent in Brazil to more than 50 per cent in Bolivia and Guatemala (Van Cott 2000: 207).

12 This institution is also known as the INI (Instituto Nacional Indigensita) which was renamed in 2003 to CONADEPI (Comisión Nacional para el Desarrollo de Pueblos Indigenas) in order to mark the shift towards a new approach, abandoning the legacy of their former assimilation policy. See also www.cdi.gob.mx Pro- 
grama nacional de desarrollo de los Pueblos Indígenas 2001-2006, I.2. Población, Diversidad Linguistica.

13 This number is based on the Mexican census, provided by the INEGI 2003 (Instituto Nacional de Estatística, Geografía y Informática). See http://www.inegi.gob. $\mathrm{mx}$. Other estimations range from 10\% to 15\% (Dehouve 2000:177).

14 In several Mesoamerican regions, especially in the Mayan area, the construction of a pan-Indian identity can be observed, see for example Nash (2001) and Fischer (2002). The emergence of a political indigenous movement in Oaxaca (COCEI) is analysed by Campbell $(1993,1994,2001)$. For political activism in response to the uprising in Chiapas see Stephen (2002:219f.).

15 Refer to El Código de Instituciones Políticas y Procedimientos Electorales which was further modified in 1997 and in 1998, see also the Aprobación de la Ley de Derechos de los Pueblos y Comunidades Indígenas (Dehouve 2000:182).

16 The size of the municipios varies from state to state. In Oaxaca, most municipios count between 1,000 and 2,000 individuals, meanwhile in Chiapas they can comprise as much as 100,000 persons. This is reflected in the number of the municipios, which are 76 in Guerrero, 112 in Chiapas and 570 in Oaxaca (Dehouve 2000:178, see also INGEI at http://www.inegi.gob.mx).

17 In some areas, especially Chatino, Mazatec or Mixe, the council of ancianos have their own president and no official can be appointed or elected to local government office without their consent. They have also the power to remove civil cargo holders whose behaviours is detrimental to community interests (Clarke 2000:194). Greenberg (1981:66) argues that the civil-religious hierarchy is embodied in the elders and the age-grades can be seen as nodal points of a control hierarchy.

18 In Yalálag women were active in the protests that followed an alleged fraudulent election in 1980. In 1981, a Unión de Mujeres Zapotecas came into existence, which has been active in community development project. As a result, women were allowed to participate in municipal meetings and political decisions (Stephen 1991:232-4). Other examples can be found in the Chatino region (Hernández Díaz 1992:128). On national level, the Mexican constitution excluded women from voting and holding elective office until 1953. Despite considerable pressure for greater involvement of women in community politics, these gender distinctions have remained enshrined at the level of the municipio. In 2004, 11 muni- 
cipios out of 570 were headed by a female presidente (INEGI, http://www.inegi. gob.mx).

19 In important urban municipios and key localities, the governor often intervenes in the selection of PRI candidates. However, in the vast majority of municipios this was unnecessary because there was no substantial organised opposition. There is also an important number of rural municipios, which were controlled by local caciques (Clarke 2000: 232).

20 The most important state programmes were PRONASOL (Programa Nacional de Solidaridad), procampo (Programa de Apoyos Directos al Campo), Progresa (Programa de Educación, Salud y Alimentación).

21 This information is based on the official Mexican census, provided by the INEGI (Instituto Nacional de Estatística, Geografía y Informática). Refer to http://www. inegi.gob.mx.

22 This does not necessarily imply that individuals can choose the jurisdiction they feel appropriate for themselves, e.g. state law or the customary law. Yrigoyen Fajardo (2004:42) discusses this issue with reference to Andean countries' constitutions. See also Van Cott (2000: 217, 228).

23 The name of the municipio is altered to guarantee confidentiality. Because of the hostility in the village, the participants in this research explicitly asked for not being identified after the interview. Detailed information about specific cases is available from the website of EDUCA, a non-governmental organisation with the aim to strengthen political and social participation of indigenous communities. See www.educaoaxaca.org and in particular www.usosycostrumbres.org.

24 Most customary practices do not date back to pre-hispanic times but are rather the result of Spanish colonial apparatus. Van Cott (2000:218) refers to the complex interaction process between the two systems by discussing a form of corporal punishment common in indigenous communities, which was adopted from Spanish colonial law, but is claimed today as an 'authentic' part of indigenous cultural heritage.

25 In the 1970s, special attention was given to bilingual education. Promotores culturales gained wide access to education and were trained as bilingual teachers, nurses and technicians or achieved other abilities for public service (Dehouve 2000:179). Between 1970 and the beginning of the 1980s their number increased 
more than $700 \%$, from 3,400 to 24,000 (Gabbert 1999:18). In the 1970s, the $\mathrm{Al}$ ianza Nacional de Profesionales Indígenas (ANPIBAC) was founded, formed by 2,00o bilingual teachers who claimed to represent the 56 linguistic groups of Mexico. Their explicit objective was to maintain the specific forms of culture of the indigenous population using bilingual and bicultural education to reinforce ethnic identity. In this context, several ethnic movements emerged in Oaxaca. Examples are given in Clarke (2000:180-182).

26 It was proposed to organise a workshop for mediation purposes with representatives from both sides. One of the group members who challenged the usos $y$ costumbres fraction told me that he was invited to take part in the workshop, but the meaning of the word workshop (taller) was not clear to him and he asked me for translation. Obviously, this group was not informed properly and did not know what to expect. Unfortunately, I was unable to attend this meeting.

\section{REFERENCES}

Anaya Múñoz, A. 2004 'Explaining the Politics of Recognition of Ethnic Diversity and Indigenous Peoples' Rights in Oaxaca, Mexico', Bulletin of Latin American Research, 23(4): 414-433.

Baumann, G. 1999 The Multicultural Riddle: Rethinking National, Ethnic, and Religious Identities, London: Routledge.

Baumann, G. 1996 Contesting Culture: Discourses of Identity in Multi-ethnic London, Cambridge: Cambridge University Press.

Beals, R. 1975 The Peasant Marketing System of Oaxaca, Berkeley and Los Angeles: University of California Press.

Campbell, H. (ed) 1993 Zapotec Struggles: Histories, Politics, and Representations from Juchitán, Oaxaca, Washington: Smithsonian Institution Press.

Campbell, H. 1994 Zapotec Renaissance: Ethnic Politics and Cultural Revivalism in Southern Mexico, Albuquerque: University of New Mexico Press.

Campbell, H. 2001 Mexican Memoir: A Personal Account of Anthropology and Radical Politics in Oaxaca, Westport, Conn: Bergin\&Garvey.

Clarke, C. 2000 Class, Ethnicity, and Community in Southern Mexico. Oaxaca's Peasantries, Oxford: Oxford University Press. 
Cohen, J. H. 1999 Cooperation and Community. Economy and Society in Oaxaca, Austin: University of Texas Press.

Cohen, J. H. 2004 The Culture of Migration in Southern Mexico, Austin: University of Texas Press.

Collier, A. G. 1999 Basta! Land and the Zapatista Rebellion in Chiapas, Revised Edition. Oakland, CA: Food First Books.

Cook, S. and J. T. Joo 1995 'Ethnicity and Economy in Rural Mexico: A Critique of the Indigenista Approach', Latin American Research Review 30 (2): 33-59.

Cook, S. and M. Diskin 1976 Markets in Oaxaca, Austin: University of Texas Press.

De la Fuente, J. 1965 Relaciones Interétnicas, Mexico: Instituto Nacional Indigenista.

Dehouve, D. 2000 'En torno a la reivindicación de “Autonomía”: Los cambios y movimientos en las zonas indígenas de México', in B. Klauke (ed) México y sus perspectivas para el siglo XX, Münster: Lit: 177-186.

Dennis, P. A. 1987 Intervillage Conflict in Oaxaca, New Brunswick and London: Rutgers University Press.

Dürr, E. 1996 Mitla zwischen Tradition und Moderne. Wandel einer zapotekischen Gesellschaft in Oaxaca, Münster: Lit.

Earle, D. and J. Simonelli 2005 Uprising of Hope. Sharing the Zapatista Journey of Alternative Development, Lanham, MD: Altamira Press.

Fischer, E. F. 2002 Cultural Logics and Global Economics. Maya Identity in Thought and Practice, Austin: University of Texas Press.

Gabbert, W. 1999 ‘Cultura, Autonomía y Estado: Movimientos Sociales Indígenas en América Latina: Interculturalidad e Identidad Indígena', in A. Koechert and B. Pfeiler (eds) Preguntas abiertas a la globalización en México, Hannover: Verlag für Ethnologie: 13-25.

Gabbert, W.2003'LaInteracción entre derecho nacionaly derechoconsuetudinario en América Latina', in A. Acuña Delgado, M. Cantón Delgado and G. Dietz 
(eds) Globalisación, Resistencia y Negociación en América Latina, Madrid: Catarata: 127-142.

Gabbert, W. 2004 'Indigenous Law as State Law - Recent Trends in Latin American Legal Pluralism, Paper presented at the 8th Biennial EASA (European Association of Social Anthropologists) Conference, Vienna, September 8-12, 2004.

Gabbert, W. 2005 ,Rechtsstaat und Rechtspluralismus in Lateinamerika', in R. Kappel, H. W. Tobler and P. Waldmann (eds) Rechtsstaatlichkeit im Zeitalter der Globalisierung, Freiburg i.Br.: Rombach Verlag: 301-318.

Gross, T. 2003 'Protestantism and Modernity: The Implications of Religious Change in Contemporary Rural Oaxaca', Sociology of Religion 64 (4):479498.

Greenberg, J. B. 1989 Blood Ties: Life and Violence in Rural Mexico. Tucson: University of Arizona Press.

Hale, C. R. 2002 'Does Multiculturalism Menace? Governance, Cultural Rights and the Politics of Identity in Guatemala', Journal of Latin American Studies 34: 485-524.

Hernández Díaz, J. 1992 Los Chatinos: etnicidad y organisacion Social, Oaxaca: Instituto de Investigaciones Sociológicas, UABJO.

Huffschmid, A. 2000 'Spinnen im Netz. Zapatismus als Maskerade und Paradoxe Politik', in U. Brand, A. E. Ceceña (eds) Reflexionen einer Rebellion. „Chiapas" und ein anderes Politikverständnis, Münster: Westfälisches Dampfboot: $136-176$.

Kuppe, R. 2001 Die Anerkennung indigener Rechtsautonomie im interkulturellen Spannungsfeld, Innsbrucker Geographische Studien, BD 32: 61-76.

Kymlicka, W. 1995 Multicultural Citizenship. A Liberal Theory of Minority Rights, Oxford: Clarendon Press.

Maranhão, T. and B. Streck 2003 Translation and Ethnography. The Anthropological Challenge of Intercultural Understanding, Tucson: University of Arizona Press. 
Marcos, Subcomandante 1997 El sueño zapatista: Conversaciones con Yvon LeBot, Mexico City: Plaza y Janes.

Marcos, Subcomandante Insurgente 2002 'Our World is Our Weapon. Selected Writings of Subcomandante Insurgente Marcos', edited by Juana Ponce de Leon. New York: Seven Stories Press.

Mattiace, S. L. $1997^{\prime}$ ¿Zapata vive!'The EZLN, Indigenous Politics, and the Autonomy Movement in Mexico, Journal of Latin American Anthropology 3 (1): 32-71.

Mattiace, S. L. 2003 To see with Two Eyes. Peasant Activism and Indian Autonomy in Chiapas, Mexico, Albuquerque: University of New Mexico Press.

Mignolo, W. D. and F. Schiwy 2003 'Double Translation: Transculturation and the Colonial Difference', in T. Maranhão and B. Streck (eds) Translation and Ethnography. The Anthropological Challenge of Intercultural Understanding, Tucson: University of Arizona Press: 3-29.

Nader, L. 1964 Talea and Juquila. A Comparision of Zapotec Social Organization, Berkeley: University of California Press.

Nader, L. 1989 'The Crown, the Colonists, and the Course of Zapotec Village Law', in J. Starr and J. F. Collier (eds) History and Power in the Study of Law, Ithaca/London: Cornell University Press: 320-344.

Nader, L. 1990 Harmony Ideology: Justice and Control in a Zapotec Mountain Village, Stanford: Stanford University Press.

Olesen, T. 2005 International Zapatismo: The Construction of Solidarity in the Age of Globalisation, London: Zed.

Rubel, P. G. and A. Rosman (eds) 2003 Translating Cultures: Perspectives on Translation and Anthropology, Oxford/ New York: Berg.

Rus, J. R., A. Hernández Castillo and S. L. Mattiace (eds) 2003 Mayan Lives, Mayan Utopias: The Indigenous Peoples of Chiapas and the Zapatista Rebellion, Lanham Md: Rowman \& Littlefield.

Rus, J. and G. A. Collier 2003 'A Generation of Crisis in the Central Highlands of Chiapas. The Cases of Chamula and Zinacantan, 1974-2000', in J. Rus, R. A. Hernández Castillo and S. L. Mattiace (eds) Mayan Lives, Mayan Utopias: 
The Indigenous Peoples of Chiapas and the Zapatista Rebellion, Lanham Md: Rowman \& Littlefield: $33-61$.

Speed, S. 2002 'Global Discourses on the Local Terrain: Human Rights and Indigenous Identity in Chiapas', Cultural Dynamics 14(2): 205-228.

Speed, S. and J. F. Collier 2000 'Limiting Indigenous Autonomy in Chiapas, Mexico: The State Government's Use of Human Rights', Human Rights Quarterly 22: 877-905.

Stephen, L. 2002 Zapata Lives! Histories and Cultural Politics in Southern Mexico, Berkeley: University of California Press.

Stephen, L. 2003 'Indigenous Autonomy in Mexico', in B. Dean and J. Levi (eds) At the Risk of Being Heard: Identity, Indigenous Rights, and Post-Colonial States, Ann Arbor: University of Michigan Press: 191-216.

Taylor, C. 1993 ,Die Politik der Anerkennung', in C. Taylor (ed.) Multikulturalismus und die Politik der Anerkennung, Frankfurt a. M.: Fischer:13-78.

Trejo, G. 2001 'The Political Foundations of Ethnic Mobilization and territorial Conflict in Mexico', México: Centro de Investigación y Docencia Económicas. No. 135 .

Van Cott, D. L. 2000 'A Political Analysis on Legal Pluralism in Bolivia and Colombia', Journal of Latin American Studies, 32: 207-234.

Velásquez Cepeda, M. C. 2000 El Nombramiento. Las elecciones por usos y costumbre en Oaxaca, Oaxaca: Instituto Estatal Electoral de Oaxaca, México.

Werbner, P. and T. Modood (eds) 1997 Debating Cultural Hybridity. Multi-Cultural Identities and the Politics of Anti-Racism, London/New Jersey: Zed Books.

Yrigoyen Fajardo, R. 2004 'Legal Pluralism, Indigenous Law and Special Jurisdiction in the Andean Countries', Beyond Law, 27:32-49. 